\title{
Influence of Soil Working Techniques and Planting Methods on Growth Performance of Fruit Plants in Kachchh Region of Gujarat, India
}

\author{
S.K. Purbey*, S.L. Meena and Rahul Dev \\ Central Arid Zone Research Institute, Regional Research Station, Kukma, \\ Bhuj (Gujarat) - 370 105, India \\ *Corresponding author
}

\begin{tabular}{|c|}
\hline Keywords \\
\hline $\begin{array}{l}\text { Aonla, Mango, } \\
\text { Custard apple, In- } \\
\text { situ, Transplanting, } \\
\text { Saucer pit, Ring pit, } \\
\text { Shelfed trench pit }\end{array}$ \\
\hline Article Info \\
\hline $\begin{array}{l}\text { Accepted: } \\
12 \text { December } 2018 \\
\text { Available Online: } \\
10 \text { January } 2019\end{array}$ \\
\hline
\end{tabular}

\section{Keywords}

Aonla, Mango, Custard apple, Insitu, Transplanting, Saucer pit, Ring pit,

\section{A B S T R A C T}

\section{Introduction}

The kachchh district of Gujarat has about $41.9 \%$ of wasteland of various categories, which are lying barren but have potential to grow fruit trees. These lands have very less soil depth and have hardpan below it. As it is well known that horticultural plants are adaptable to the extreme agro-climate, in addition they can also supply products for sustained economic returns and nutritional security to the people (Pareek, 1977). However, interaction with farmers in the present scenario and available literature revealed that growth, productivity and economic life of fruit trees are very poor in kachchh. Kachchh region has $<1 \%$ area under fruit crops due to their poor field performance 
and economic life. However, there is vast land resource, surplus family labors, increasing canal irrigated area, developing infrastructural facilities, plenty of solar and wind energy, etc. are the strength in the region for research and development of arid horticulture. Water resources in those areas are very scarce due to undulating land condition, low rainfall, high temperature and evaporation. Therefore, water conservation in the arid and semi arid regions is an important issue that influences both the environment and crop production. Good soil management practices is utmost important to store and conserve soil moisture as much rainfall as possible by reducing the run off an increasing the storage capacity of soil profile. Many factors like evapotranspiration, present of organic matter, crop rotation etc. influence the conservation of moisture content in soil. In-situ soil moisture conservation is achieved through rain water harvesting on-farm. There are so many types of in-situ moisture conservation method like micro-catchments are simply basins, formed in such a way that a gentle slope is given towards the base of stem of orchard trees so that the harvested rain water could be gathered to the maximum level, so runoff is reduced and increased the infiltration to the plant roots. Several researches have shown that in-situ moisture conservation methods have beneficial effects for the cultivation of different fruit crops in the arid and semi arid regions like pomegranate, ber, aonla, custard apple, tamarind etc (Vishalnath et al., 2000). On the other hand, conventional transplanting processes can be quite stressful for a tree. Nursery grown trees can lose a significant portion of their roots during transplanting. Establishment and optimum productivity of fruit trees largely depend upon the growth and proliferation of their root system. The root cause of this is at root itself besides, planting technique. Therefore, under such typical ecological and pedological conditions, special technique is required for successful plantation of fruit crops. Therefore, it is urgently required to identify best practices for tree handling and installation which can reduce negative impacts to a tree's long-term growth and survival. This paper details some key considerations to promote successful tree planting. Therefore, it is essential to develop technology for better growth and economic longevity of fruit crops.

\section{Materials and Methods}

The soil of the experimental site was gravelly sand to loamy sand with shallow depth $(15-$ $25 \mathrm{~cm})$, EC value ranging from 2 to $6.38 \mathrm{dS} / \mathrm{m}$ and $\mathrm{pH}$ from 8.4 to 9.2 . The soil contained $0.25 \%$ organic carbon, $7.35 \mathrm{~kg} \mathrm{P}_{2} \mathrm{O}_{5}$ and 215 $\mathrm{kg} \mathrm{K} \mathrm{K}_{2} \mathrm{O} \mathrm{ha}{ }^{-1}$. As per the plan of research activities, different size of pits was prepared in the month of May and was filled with proper soil mixture in the month of June. In the last week of June the mango stones and aonla seeds were sown in the field as well as in nursery. Different types of soil working structures were prepared during August. In September, seeds of custard apple were sown in the field as well as in the nursery. Six months old seedlings of mango and aonla were transferred in the main field in the month of December, whereas custard apple seedlings were shifted in the month of March.

As per the technical programme, the seedlings were planted in the pits which were filled with soil mixture of topsoil, farmyard manure and sand in the ratio of $1: 1: 1$. In a microcatchment, which may be triangular or rectangular, trees are planted at the lowest point where runoff accumulates. The experiments were laid out in split plot design with three replications using 3 plants as an experimental unit. The planting techniques treatments i.e. direct sowing of seed at planting site (A1), sowing of nursery raised seedling (A2), were put under main plots. The different type of soil working techniques viz., 
ordinary pit $(\mathrm{C} 1)$, saucer pit $(\mathrm{C} 2)$, ring pit (C3), and shelf trench (C4) were in sub plots. The observations related to germination, initial and final survival was expressed in terms of percentage. The observations related to time taken for germination, plant height $(\mathrm{cm})$ and girth $(\mathrm{cm})$ were also recorded and results were analyzed statistically. Other cultural operations were done as per recommended practices.

The fruit species experimented were mango, aonla and custard apple planted at the spacing (m) of $(8 \times x),\left(\begin{array}{lll}6 & x & 6\end{array}\right)$ and $\left(\begin{array}{lll}8 & x & 8\end{array}\right)$, respectively.

\section{Results and Discussion}

\section{Rainfall pattern}

During the crop period of Ist year (2005) monsoon started from July, $1^{\text {st }}$ and continued up to $20^{\text {th }}$ September. The area received a total of $238.2 \mathrm{~mm}$ rains during this period, but there were only four days having more than $10 \mathrm{~mm}$ rains. A long dry spell between two rainy days caused perpetual drought during cropping. The rainfall during the second year started from June $26^{\text {th }}$ and continued up to $21^{\text {st }}$ August. During this period more than twelve days had effective rainfall. The total amount of rains received during this period was $689.4 \mathrm{~mm}$, about 110 percent more than annual average (326 mm) of area (Fig. 1).

\section{Influence of planting techniques on growth performance of the fruit plants}

The results related to growth performance of nursery raised seedlings and in-situ grown seedlings indicated that under nursery condition, the germination and girth index of these fruit plants were better than that of under in-situ condition; however, plant height was found more under in-situ raised plants. The survival percentage was recorded significantly higher in nursery raised seedlings $(93.75$, and 84.00) as compared to in-situ raised seedlings (86.75 and 71.75) in Aonla and custard apple, respectively at 90 days after sowing (DAS) (Table 1).

However, survival percent after first year of planting was higher in Aonla and Mango plants raised directly in the field than under nursery condition. Whereas in case of custard apple there was not much difference. The plant height of in-situ raised seedlings were about 24 and 21 percent more in Aonla, 19 and 24 percent more in custard apple than that of nursery raised plants at 180 DAS and 730 DAS respectively (Table 2), whereas it was found at par in case of mango. The germination time in days were found significantly less in nursery condition than that in direct seed sown in the field (Table 1).

A comparative study of in-situ and nursery raised fruit plants in the second year of growth indicated that in-situ raised Aonla plant had shown significantly higher growth (20.82 percent more) compared to nursery raised plants. This might be due to the loss of tap root as a result of repeated transplanting. For success in dry lands, plants must have root architecture with a strong tendency to penetrate deep into the soil, therefore, in-situ technique of orchard establishment is found suitable under arid conditions (Vishalnath et al., 2000).

The collar girth however, was more in nursery-raised plants. In custard apple, plantings techniques did not have any effect on growth performance (Table 6). The fruit plants rose through nursery performed better because favourable conditions could be managed under small area. These findings are with the conformity of Gangolly et al., (1957) and Ram (1987) (Table 3, 4 and 5). 
Table.1 Effect of planting and moisture conservation techniques on growth performance of Aonla

\begin{tabular}{|c|c|c|c|c|c|c|}
\hline \multirow[t]{2}{*}{ Treatments } & \multicolumn{3}{|c|}{ Plant height (cm.) } & \multicolumn{3}{|c|}{ Collar Diameter (cm) } \\
\hline & $180 \mathrm{DAS}$ & 365 DAS & 730 DAS & 180 DAS & 365 DAS & 730 DAS \\
\hline \multicolumn{7}{|c|}{ Water harvesting pits } \\
\hline Ordinary (C1) & 32.81 & 89.00 & 156.21 & 0.83 & 1.88 & 2.85 \\
\hline Saucer (C2) & 46.74 & 106.83 & 173.74 & 1.06 & 2.15 & 3.25 \\
\hline Ring (C3) & 48.43 & 100.44 & 164.67 & 0.94 & 1.95 & 3.11 \\
\hline $\begin{array}{l}\text { Shelf Trench } \\
\text { (C4) }\end{array}$ & 44.14 & 101.05 & 170.56 & 0.97 & 1.98 & 3.06 \\
\hline Mean & 43.03 & 99.33 & 166.30 & 0.95 & 1.99 & 3.07 \\
\hline CD $(5 \%)$ & 2.33 & 4.51 & 5.06 & 0.21 & 0.28 & 0.32 \\
\hline \multicolumn{7}{|c|}{ Planting techniques } \\
\hline In-situ & 47.60 & 107.3 & 170.5 & 0.93 & 1.96 & 2.81 \\
\hline Nursery raised & 38.40 & 82.4 & 161.2 & 1.10 & 2.15 & 3.23 \\
\hline Mean & 43.00 & 94.85 & 168.1 & 1.02 & 2.06 & 3.02 \\
\hline CD $(5 \%)$ & NS & 3.26 & 2.04 & NS & 0.33 & 0.27 \\
\hline
\end{tabular}

Table.2 Effect of planting and moisture conservation techniques on germination and survival of Aonla

\begin{tabular}{|l|c|c|c|c|c|}
\hline \multirow{5}{*}{ Treatments } & \multicolumn{5}{|c|}{ Survival (\%) } \\
\cline { 2 - 6 } & $\begin{array}{l}\text { Germination } \\
\text { time (Days) }\end{array}$ & $\begin{array}{l}\text { Germination } \\
(\%)\end{array}$ & 90 DAS & 180 DAS & 365 DAS \\
\hline Water harvesting pits & \multicolumn{3}{|l|}{} & \\
\hline Ordinary (C1) & 9.42 & 64.15 & 80.16 & 71.06 & 80.27 \\
\hline Saucer (C2) & 7.88 & 76.25 & 92.07 & 80.52 & 91.55 \\
\hline Ring (C3) & 8.34 & 69.88 & 92.86 & 84.06 & 92.69 \\
\hline $\begin{array}{l}\text { Shelf Trench } \\
\text { (C4) }\end{array}$ & 8.37 & 70.12 & 94.85 & 85.84 & 94.63 \\
\hline Mean & 8.50 & 70.10 & 89.98 & 80.37 & 89.78 \\
\hline CD (5\%) & 1.21 & 2.67 & 2.86 & 1.97 & 1.89 \\
\hline Planting techniques & & & & & \\
\hline In-situ & 8.67 & 69.00 & 81.75 & 78.02 & 86.76 \\
\hline Nursery raised & 6.84 & 81.31 & 93.75 & 80.63 & 82.34 \\
\hline Mean & 7.76 & 75.16 & 87.75 & 79.43 & 84.55 \\
\hline CD (5\%) & 1.02 & 4.03 & 4.65 & NS & 3.67 \\
\hline
\end{tabular}


Table.3 Effect of planting and moisture conservation techniques on germination and survival of Mango plant

\begin{tabular}{|l|c|c|c|c|c|}
\hline \multirow{5}{*}{ Treatments } & \multicolumn{5}{|c|}{ Survival (\%) } \\
\cline { 2 - 6 } & $\begin{array}{l}\text { Germination } \\
\text { time (Days) }\end{array}$ & $\begin{array}{l}\text { Germination } \\
(\%)\end{array}$ & 90 DAS & 180 DAS & 365 DAS \\
\hline Water harvesting pits & \multicolumn{3}{|l|}{} & \\
\hline Ordinary (C1) & 36.34 & 64.57 & 65.21 & 69.43 & 74.13 \\
\hline Saucer (C2) & 33.13 & 75.88 & 69.03 & 73.52 & 83.24 \\
\hline Ring (C3) & 32.67 & 72.37 & 75.53 & 73.99 & 83.67 \\
\hline $\begin{array}{l}\text { Shelf Trench } \\
\text { (C4) }\end{array}$ & 33.24 & 76.98 & 81.56 & 75.22 & 84.34 \\
\hline Mean & 33.85 & 72.45 & 72.83 & 73.04 & 81.35 \\
\hline CD (5\%) & $\mathrm{NS}$ & 4.26 & 6.23 & & 4.12 \\
\hline Planting techniques & & & & & \\
\hline In-situ & 35.67 & 67.00 & 72.88 & 74.56 & 83.13 \\
\hline Nursery raised & 29.34 & 74.13 & 74.24 & 75.13 & 80.67 \\
\hline Mean & 32.50 & 70.56 & 73.56 & 74.84 & 81.90 \\
\hline CD (5\%) & 4.42 & 5.67 & NS & NS & 2.69 \\
\hline
\end{tabular}

Table.4 Effect of planting and moisture conservation techniques on growth performance of Mango plant

\begin{tabular}{|l|c|c|c|c|c|c|}
\hline \multirow{2}{*}{ Treatments } & \multicolumn{5}{|c|}{ Plant height (cm.) } & \multicolumn{3}{c|}{ Collar Diameter (cm) } \\
\cline { 2 - 7 } & 180 DAS & 365 DAS & 730 DAS & 180 DAS & 365 DAS & 730 DAS \\
\hline Water harvesting pits & \multicolumn{3}{|c|}{} & \\
\hline Ordinary (C1) & 54.57 & 73.00 & 102.34 & 0.83 & 1.34 & 2.03 \\
\hline Saucer (C2) & 61.37 & 81.54 & 118.88 & 0.94 & 1.47 & 2.22 \\
\hline Ring (C3) & 60.14 & 77.13 & 119.67 & 0.91 & 1.39 & 2.14 \\
\hline $\begin{array}{l}\text { Shelf Trench } \\
\text { (C4) }\end{array}$ & 63.08 & 80.50 & 112.34 & 0.93 & 1.42 & 2.19 \\
\hline Mean & 59.97 & 78.04 & 113.30 & 0.90 & 1.40 & 2.15 \\
\hline CD (5\%) & 3.21 & 4.56 & 4.12 & NS & NS & 0.05 \\
\hline Planting techniques & & & & & \\
\hline In-situ & 60.40 & 81.13 & 113.67 & 0.84 & 1.38 & 2.05 \\
\hline Nursery raised & 59.20 & 73.89 & 115.88 & 0.95 & 1.44 & 2.18 \\
\hline Mean & 59.80 & 77.51 & 114.77 & 0.89 & 1.41 & 2.12 \\
\hline CD (5\%) & NS & 3.25 & NS & 0.03 & NS & NS \\
\hline
\end{tabular}


Table.5 Effect of planting and moisture conservation techniques on growth performance of Custard apple plant

\begin{tabular}{|l|c|c|c|c|c|c|}
\hline \multirow{2}{*}{ Treatments } & \multicolumn{5}{|c|}{ Plant height (cm.) } & \multicolumn{3}{c|}{ Collar Diameter (cm) } \\
\cline { 2 - 7 } & 180 DAS & Ist Year & IInd Year & 180 DAS & 365 DAS & 730 DAS \\
\hline Water harvesting pits & \multicolumn{5}{|c|}{} \\
\hline Ordinary (C1) & 33.14 & 71.54 & 99.56 & 0.43 & 1.22 & 1.83 \\
\hline Saucer (C2) & 41.67 & 84.08 & 112.77 & 0.55 & 1.53 & 1.99 \\
\hline Ring (C3) & 40.56 & 76.67 & 105.14 & 0.49 & 1.49 & 1.95 \\
\hline $\begin{array}{l}\text { Shelf Trench } \\
\text { (C4) }\end{array}$ & 45.18 & 73.54 & 108.37 & 0.57 & 1.44 & 2.04 \\
\hline Mean & & & & & & \\
\hline CD (5\%) & 40.14 & 76.46 & 106.46 & 0.51 & 1.42 & 1.95 \\
\hline Planting techniques & & & & & \\
\hline In-situ & 43.40 & 86.37 & 131.67 & 0.47 & 1.32 & 1.98 \\
\hline Nursery raised & 36.34 & 63.67 & 106.34 & 0.56 & 1.45 & 2.08 \\
\hline Mean & 39.87 & 75.02 & 119.00 & 0.52 & 1.39 & 2.03 \\
\hline CD (5\%) & 5.54 & NS & 5.19 & 0.06 & 0.09 & NS \\
\hline
\end{tabular}

Table.6 Effect of planting and moisture conservation techniques on germination and survival of Custard apple plant

\begin{tabular}{|l|c|c|c|c|}
\hline \multicolumn{1}{|c|}{ Treatments } & \multicolumn{3}{c|}{ Survival (\%) } \\
\cline { 2 - 5 } & $\begin{array}{c}\text { Germination } \\
\text { time (Days) }\end{array}$ & $\begin{array}{c}\text { Germination } \\
(\%)\end{array}$ & 90 DAS & 180 DAS \\
\hline Water harvesting pits & \multicolumn{3}{|c|}{} \\
\hline Ordinary (C1) & 42.37 & 59.98 & 70.06 & 77.27 \\
\hline Saucer (C2) & 34.88 & 70.37 & 80.52 & 91.55 \\
\hline Ring (C3) & 36.14 & 68.67 & 84.06 & 92.69 \\
\hline Shelf Trench (C4) & 35.07 & 72.24 & 85.84 & 94.34 \\
\hline Mean & 37.11 & 67.82 & 80.12 & 88.96 \\
\hline CD (5\%) & NS & 5.12 & 3.32 & 6.17 \\
\hline Planting techniques & & & & 81.73 \\
\hline In-situ & 41.34 & 61.88 & 71.75 & 87.61 \\
\hline Nursery raised & 34.13 & 75.00 & 84.00 & 84.67 \\
\hline Mean & 37.74 & 68.44 & 77.86 & 4.77 \\
\hline CD (5\%) & 6.03 & 5.69 & 6.15 & \\
\hline
\end{tabular}


Fig.1 Rainfall pattern during I and II Year of experimentation
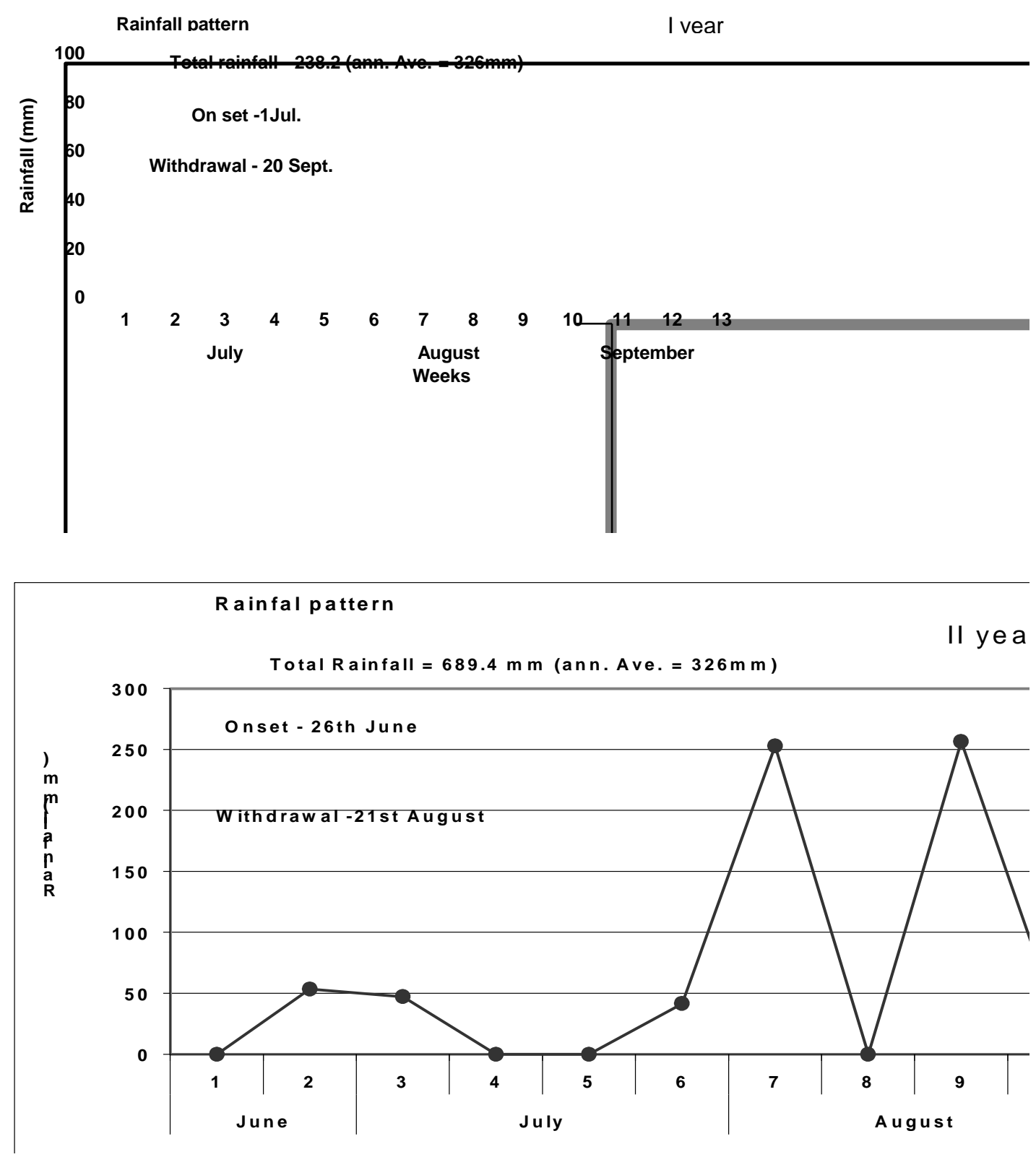

Influence of soil working structures on growth performance of the fruit plants

The soil working structures had significant effect on germination and survival percentage, plant height, and collar diameter. The plant height and collar diameter were more in those planted in saucer shaped pit as compared to other soil working structures irrespective of fruit species planted. Aonla plants raised in saucer structure showed 11.22 percent more height than ordinary water harvesting structure (Table 1). The collar diameter also followed similar pattern (Table 1). Better vegetative growth and yield in saucer (cup and plate) system, might be due to more rainwater harvesting by this structure and the resultant increased soil water availability to plants for longer duration as compared to other structures. Negi (2013); 
Polara (2013) and Patil (2005) have reported the similar beneficial effects of rain water harvesting techniques on plant growth and fruit yield in, custard apple and mango, respectively. Survival percentage was observed higher under C4 (Shelfed trench) soil working treatments, as compared with rest of the soil working techniques irrespective of fruit crops. Saucer shaped pit supported better growth than ring and shelfed trench. The better performance of saucer shaped water harvesting system might be due to uniform availability and distribution of soil moisture around the active root zone and their translocation to aerial part of the tree and thereby increased the vegetative growth of tree. Aonla plants performed better followed by Custard apple and Mango. The soil working structure of saucer shaped had better effect on plant height and collar diameter because of its more water harvesting nature. On the other hand plant survived more under shelfed trench because of moisture conservation for longer period. Gupta, 1983 and Saroj et al., 1994 also revealed the similar results in other findings. Badhe and Magar (2004), Khola and Sastry (2005), Manivannan and Desai (2007) and Panigrahi (2008) reported that in situ rain water harvesting by trenching, bunding, circular basins can increase soil water content by reducing surface runoff and encouraging infiltration in different fruit crops. The soil working structure allow rain water retention for a prolonged duration on the soil surface for increased infiltration and retention and better rain water use efficiency (Itabari, 1999).

In conclusion, the fruit plants raised in the nursery are generally used to establish orchards. Such plants invariably lose their tap roots as a result of repeated transplanting. Plants raised in containers develop coiled roots. For success in dry lands, plants must have root architecture with a strong tendency to penetrate deep into the soil. The germination time and percentage was more in nursery raised seedlings as compared to direct seeding in the field. Among the various soil working structures saucer system has performed better in terms of plant height and collar diameter as compared to other soil working structures. The survival percentage was observed highest in trench system of water harvesting techniques as well as in situ planting. Among the different fruit species Aonla performed better than mango and custard apple.

\section{References}

Badhe V T and Magar S S. 2004. Influence of different conservation measures on runoff, soil and nutrient loss under cashew nut in lateritic soils of South Konkan region. Indian Journal of Soil Conservation 32: 143-47.

Gangolly, A. Singh, S. R. Katyal, S. L. and Singh, D. 1957. The Mango, Indian Council of Agricultural Research, New Delhi., p.p. -235.

Gupta, T. 1983. The economics of tree crops on marginal agricultural lands with special reference to the hot arid regions of Rajasthan. Intern. Tree Cops J. 2(2): $155-94$.

Haridayal, Meghwal, P.R. and Singh, Dheeraj. 2010. Effect of Variety, Time and Method of In Situ Budding on Bud Take in Aonla (Emblica officinalis Gaertn) in Arid Zone. Annals of Arid Zone 49(1): 77-78.

Itabari, J.K. (1999) 'Optimizing soil water use in the Semi-Arid Areas of Kenya', Efficient Soil Water Use: the key to Sustainable Crop Production in Dry Areas. Proceedings of the workshops organized by the Optimizing Soil Water Use Consortium, 26-30 April, Niamey, Niger, pp.85-104.

Khola, O. P. S. and Sastry, G. (2005). Conservation efficiency of mechanical 
measures and productivity of maizewheat cropping sequence under different land slopes in foothills of western Himalaya. Indian Journal of Soil Conservation 33(3): 221-224.

Negi, R. S., Baghel, B. S., Gupta, A. K and Singh, Y. K. (2013). Effect of moisture conservation on plant growth and nutrient uptake in aonla (Emblica officinalis Gaertn) in sloppy degraded lands. Hort Flors Research Spectrum 2 (1): 1-7.

Panigrahi, P., Huchehe, A. D, Srivastava, A. K. and Singh, S. (2008). Effect of drip irrigation and plastic mulch on performance of Nagpur mandarin () grown in central India. Indian Journal of Agricultural Sciences 78(12): 10051009.

Pareek, O. P. 1977. Horticulture in arid zone ecosystem; Fruit growing (In): Desert Eco-system and its improvement (Ed) Maan, H. S. CAZRI, Jodhpur. p.p. 213 -22 .

Pareek, O.P. and Sharma, Suneel 1991. Fruit trees for arid and semi-arid lands. Indian Farming 41: 25-30

Patil, D. R., Patil, H. B., Prashanth, J. M. and Patil, S. N. (2005). Evaluation of water harvesting techniques and use of low cost mulching materials in mango cv. Alphonso.Karnataks Journal of Agricultural Sciences 18 (4): 1160-
1162.

Polara, N. D., Chovatia, R. S., Delvadia, D. V., Joshi, N. S. and Dulawat, M. S. (2013). Effect of different in situ water harvesting techniques and low cost mulching in custard apple. Journal of Chemical, biological and physical science 3(2): 1607-1612

Ram, S. 1983. Aonla (Emblica officinalis, Gaetrn) uses, botany and cultivation. Directorate of Experimentation, G. B. Pant University of Agric. \& Technology, Pantnagar. pp. 233.

Saroj, P. L. Dubey, K. C. and Tiwari, R. K. 1994. Utilization of degraded lands for fruit production. Indian J. Soil Cons. 22: $162-176$

Sharma, K.D., Pareek, O.P. and Singh, H.P. 1986. Micro-catchment water harvesting for raising jujube orchards in arid climate. Trans. ASAEI 29: 112118.

Sharma, S. K., Singh, R. S.and Bhargava, R. 2013. Arid Horticulture: An Overview. Annals of Arid Zone 52(3\&4): 251-264.

Sharma, S.K., Singh, R.S. and Bhargava, R 2013. Arid Horticulture: An Overview. Annals of Arid Zone 52(3\&4): 251-264.

Vishal Nath, Saroj, P.L., Singh, R.S., Bhargava, R. and Pareek, O.P. 2000. Insitu establishment of ber orchards under hot arid eco-system in Rajasthan. Indian Journal of Horticulture 57(1): 21-26.

\section{How to cite this article:}

Purbey, S.K., S.L. Meena and Rahul Dev. 2019. Influence of Soil Working Techniques and Planting Methods on Growth Performance of Fruit Plants in Kachchh Region of Gujarat, India. Int.J.Curr.Microbiol.App.Sci. 8(01): 1874-1882. doi: https://doi.org/10.20546/ijcmas.2019.801.197 